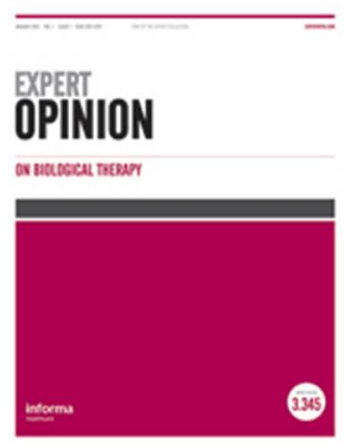

Please download and read the instructions before proceeding to the peer review

\title{
Decellularised material as scaffolds for tissue engineering studies in long gap oesophageal atresia
}

\begin{tabular}{|r|l|}
\hline Journal: & Expert Opinion On Biological Therapy \\
\hline Manuscript ID & EOBT-2016-0232.R1 \\
\hline Manuscript Type: & Review \\
\hline Keywords: & $\begin{array}{l}\text { bioethics, decellularisation, oesophageal atresia, scaffolds, tissue } \\
\text { engineering }\end{array}$ \\
\hline \multicolumn{2}{|l}{} \\
\hline
\end{tabular}

SCHOLARONE ${ }^{\text {m }}$

Manuscripts 


\section{Review:}

\section{Decellularised material as scaffolds for tissue engineering studies in long gap}

oesophageal atresia.

Esmond Lee, BEng MSc PhD Candidate. ${ }^{1,2,3}$

Centre for Cell, Gene \& Tissue Therapeutics, Royal Free Hospital, London UK

Stanford University, Institute for Stem Cell Biology and Regenerative Medicine, USA

Bioprocessing Technology Institute, A*STAR, Singapore

Anna Milan, MD PhD. ${ }^{4}$

Stem Cells \& Regenerative Medicine Section

UCL Great Ormond Street Institute of Child Health, London UK

Luca Urbani, PhD Research Associate. ${ }^{4}$

Stem Cells \& Regenerative Medicine Section

UCL Great Ormond Street Institute of Child Health, London UK

Paolo De Coppi, MD PhD NIHR Professor of Paediatric Surgery. ${ }^{4}$

Head of Stem Cells \& Regenerative Medicine Section

UCL Great Ormond Street Institute of Child Health, London UK

Mark W Lowdell, PhD. ${ }^{1}$

Director of the Centre for Cell, Gene \& Tissue Therapy

Royal Free Hospital, London UK

1 Centre for Cell, Gene \& Tissue Therapeutics, Royal Free Hospital, London UK

2 Stanford University, Institute for Stem Cell Biology and Regenerative Medicine, USA

3 Bioprocessing Technology Institute, A*STAR, Singapore

4 Stem Cells and Regenerative Medicine Section, UCL Great Ormond Street Institute of

Child Health, London UK

\section{Corresponding Author:}

Anna Milan, MD PhD

Stem Cells and Regenerative Medicine Section,

UCL Great Ormond Street Institute of Child Health,

London UK

Dr.annamilan@gmail.com

TEL. +447453709522 
Introduction: Oesophageal atresia refers to an anomaly in foetal development in which the oesophagus terminates in a blind end. Whilst surgical correction is achievable in most patients, when a long gap is present it still represents a major challenge associated with higher morbidity and mortality. In this context, tissue engineering could represent a successful alternative to restore oesophageal function and structure. Naturally derived biomaterials made of decellularised tissues retain native extracellular matrix architecture and composition, providing a suitable bed for the anchorage and growth of relevant cell types.

Areas covered: This review outlines the various strategies and challenges in oesophageal tissue engineering, highlighting the evolution of ideas in the development of decellularised scaffolds for clinical use. It explores the interplay between clinical needs, ethical dilemmas, and manufacturing challenges in the development of a tissue engineered decellularised scaffold for oesophageal atresia.

Expert opinion: Current progress on oesophageal tissue engineering has enabled effective repair of patch defects, whilst the development of a full circumferential construct remains a challenge. Despite the different approaches available and the improvements achieved, a gold standard for fully functional tissue engineered oesophageal constructs has not been defined yet.

\section{Introduction:}

Oesophageal atresia (OA) is a congenital anomaly that affects 1:2500-5000 newborns [1]. In children born with the condition the continuity of the oesophagus is interrupted by a blind end. This prevents swallowed material from entering the stomach and requires surgery to create a clear passage for food. Atresia presents most commonly with distal tracheooesophageal fistula (TOF), where the proximal oesophagus ends blindly at the level of about 
the third or fourth thoracic vertebra while the distal oesophagus, enters the posterior wall of the trachea [1].

From a structural point of view, OA can be classified based on the presence and position of the tracheo-oesophageal fistula (TOF) according to Gross classification [2]:

- type A: isolated oesophageal atresia ( $8-9 \%$ of OA cases)

- type B proximal fistula with distal atresia (1\%)

- type C: proximal atresia with distal fistula (85\%)

- type D: double fistula with intervening atresia (1-2\%)

- type E: isolated fistula (4-6\%)

When a distal TOF is not present (type A and B) there is usually a long gap between the 2 ends of the oesophagus and reconstruction is particularly challenging.

An antenatal ultrasound scan after 18 gestation weeks can detect signs of possible OA, particularly when there is no distal fistula and the baby is unable to swallow amniotic fluid, therefore making the stomach not visible. A definitive diagnosis however is usually made once the infant is born (Fig.1). Due to the impossibility of feeding the baby and the high risk of respiratory complications and failure, surgical intervention in the first days of life is required to stabilise the patient and repair the anomaly [3]. From the first reported successes in operative procedures in the 1940 s, rates have been rising steadily due to improvements in surgical techniques [1] and neonatal units today often report overall operative success rate exceeding 95\% [4]. However, these patients face post-operative complications that lead to a lower quality of life. These comprise of anastomotic leakage or strictures, gastro-oesophageal reflux and oesophageal dysmotility (Tab.1), all of which lead to recurrent hospitalisation and multiple surgical treatments. 
Patients with long gap oesophageal atresia (LGOA) however, suffer the highest complication rates. Since oesophageal continuity cannot be achieved in a single surgery, a multi-step approach is required. A common strategy is for the patient to undergo surgery for gastrostomy formation in the first days of life. This will allow the baby to be fed while waiting for the oesophagus to naturally grow until a tension free anastomosis is technically feasible. Throughout this waiting period, which could last weeks or months, patients cannot however be discharged home. They are bound to an intensive care unit in view of the high risk of respiratory complications related to the abundant secretions that need to be constantly removed from the upper pouch with the use of a suctioning tube. When, insufficient spontaneous growth is experienced or anticipated, a different approach is adopted which involves lengthening procedures performed to directly and progressively reduce the gap between the two oesophageal pouches, allowing a subsequent tension-free anastomosis. There are instances, finally, where the only feasible option is oesophageal replacement. In these settings, a gastric transposition, colonic interposition or jejunal interposition represent the best available options [5]. Among them the gastric route involves transposing the whole stomach into the thoracic region and is preferred for the excellent blood supply of the stomach. Nevertheless, several complications can occur including: anastomotic leaks, strictures, reflux, dumping, poor gastric emptying and Barrett's esophagitis [6].

In this context, developing a tissue engineered oesophageal replacement to repair a long gap defect would lead to better long term clinical outcomes [7]. Synthetic materials used in other surgical settings include polyglycolic acid (Vicryl $\left.{ }^{\circledR}\right)$ and crystalline polypropylene and highdensity polyethylene (Marlex $\left.{ }^{\circledR}\right)$. They can provide mechanical support, but fail to fully mimic the specific host tissue function and would not follow the growth of the oesophagus during childhood. More recent approaches have used hybrid scaffolds containing cells or extracellular matrix (ECM), as well as decellularised tissues. These tissues are naturally 
derived and can better mimic the complexity of native ECM architecture [8]. This review aims to describe the development of tissue engineered oesophageal constructs for LGOA with a focus on decellularised tissue. It expounds on the clinical relevance of these studies, and on the hurdles to be overcome in developing such construct for clinical use.

\section{Discussion}

\subsection{Anatomy of the oesophagus}

The oesophagus is a muscular tube that connects the pharynx to the stomach, enabling the passage of food and liquids. In humans, the muscle layers in the upper (cervical) part of the oesophagus are predominantly made of skeletal muscle, while the lower (thoracic) portion consists predominantly of smooth muscle cells [9]. These muscle strata represent the external layer of the oesophagus. Proceeding towards the lumen there is a second layer formed by submucosa that contains the main blood vessels, the submucosal (Meissner) nerve plexus, and oesophageal glands. Finally, the mucosa forms the innermost layer and is characterised by a nonkeratinizing stratified epithelium that changes from squamous cell epithelium (continuous with that of the pharynx) to columnar cell epithelium (at the gastroesophageal junction). The oesophagus shows increasing stiffness with pressure. While small intraluminal pressures are held by the muscle alone, mucosal contribution to strength increases after the outer diameter of the oesophagus doubles [10].

\subsection{Approaches to Oesophageal Regeneration}

Early approaches to tissue engineering of the oesophagus employed synthetic materials rolled into a tubular configuration $[11,12,13]$. Although they provided mechanical support, these constructs were not designed to interact with the in vivo environment to promote 
regeneration. Most recent approaches combine synthetic materials with biological components to make a hybrid scaffold $[14,15,16]$. Materials of biological origin have been recognised as capable of better replicating the composition, microstructure, and properties of native tissue [8]. It is inevitable that the discussion on regenerative approaches for the oesophagus draws on the wealth of research involving naturally derived constructs such as decellularised tissues (Fig.2).

\subsubsection{Synthetics and Hybrid Scaffolds}

For over 165 years, various techniques have been tested as oesophageal replacements in oesophageal cancer including decalcified ivory tubes and rubber tubes [17]. In more recent history, surgical polymers such as Dacron ${ }^{\circledR}$ and Marlex ${ }^{\circledR}$ have been used alone or in combination with silicone to produce synthetic grafts $[12,13,14]$. In 1983, Fukushima et al. reported the use of a silicone tube surrounded by a Dacron mesh [14]. The survival rate after implantation into canine models was $44 \%$ at 1 year and $25 \%$ at 6 years. They observed the regeneration of the submucosa and mucosa in contact with the anastomoses, but there were no glands or muscle tissue, and the central part of the tube consisted of fibrotic tissue. In 2010, Liang [18] used a nitinol-silicon composite artificial oesophagus in pigs. The rate of stenosis was $60 \%$, and regeneration of a stratified epithelium was only found near the anastomosis. These studies provide strong evidence that although they offer mechanical support, synthetic materials alone are unable to promote tissue regeneration.

Nakase in 2008 developed a scaffold consisting of absorbable polyglycolic acid associated with a sheet of amniotic membrane to which smooth muscle tissue was added [19]. Resorbable scaffolds in one group were further seeded with keratinocytes and fibroblasts. After implantation in dogs, stenosis was observed less than a week after implantation in the scaffolds without seeded cells. This complication did not occur in the cell seeded group. 
Beckstead in 2005 developed scaffolds composed of polylactic acid, poly(lactic-co-glycolic acid) or polycaprolactone with different porosities and studied the effects on cell adhesion and proliferation [20]. Studies exploring the balance between the rate of material degradation and tissue remodelling are crucial because rapid scaffold degradation can lead to the collapse of mechanical support, while too slow degradation may impede tissue remodelling $[21,22,23]$. Recently, biological components such as cells, proteins, or specific peptide motifs were included in tissue engineered constructs, leading to better outcomes. Kitajima worked on a cell-seeded poly-glycolic acid mesh containing collagen [24] while Zhu used a series of Poly-DL-lactide polymers in conjunction with ECM proteins to promote oesophageal tissue regeneration $[25,26]$. Other biological material such as Alloderm ${ }^{\circledR}($ decellularised dermis) or amniotic membrane have also been used [20]. More recent studies explored the effect of seeding appropriate cell types onto scaffolds. Saxena [27,28] experimented seeding oesophageal epithelial cells onto collagen scaffolds as part of a composite scaffoldhetrocellular oesophagus, showing that seeding of a specific epithelial population leads to more viable scaffolds, while Nakase [19] described how seeding of a resorbable scaffold with keratinocytes and fibroblasts reduced complications of post implantation stenosis. 3D topography of scaffolds can also provide cues for regeneration. Hou in 2016 developed polyester-urethane scaffolds coated with vascular endothelial growth factor. The group showed that $3 \mathrm{D}$ patterned micro-grooves aligned in the direction of muscle fibres promoted muscle tissue regeneration [29].

\subsubsection{Decellularised Scaffolds}

\subsubsection{Overview}

Despite growing knowledge of synthetics constructs, naturally derived scaffolds such as decellularised tissue can better mimic the complexity of native ECM architecture [8] and have been successfully used to regenerate children airway tissue [30]. Naturally derived 
scaffolds may better mimic the physical microenvironment; providing more physiological substrate rigidity which impacts on stem cell fate and endogenous repair [31,32]. In addition to structural support, ECM exerts pleiotropic effects on cells, enabling cell anchorage, growth, and signalling to occur $[33,34,35]$. Hence, the retention of native ECM architecture is a priority in the decellularisation process. Table 2 provides an overview on decellularisation agents, in vivo procedures and post-operative outcomes from each oesophageal engineering study.

Most studies involving decellularised tissue use scaffolds from the gastro-intestinal (GI) tract such as Surgisis ${ }^{\circledR}$, which is an off-the-shelf product made from small intestinal submucosa (SIS). Its use in oesophageal tissue engineering has been studied in animal models (canine, porcine, rat) as well as in two clinical cases (Tab.2).

The majority of the published studies were conducted in the cervical region. Considering the differences in muscle types and nervous control, engineering and surgical implantation of a cervical tissue oesophageal segment may differ substantially from that of a thoracic segment. In the next future it will be important to address the dearth of studies on the replacement of the thoracic oesophagus, which may be more clinically relevant in LGOA.

\subsubsection{Strategies in repairing full circumferential defects}

Within the studies described in Table 2, there is a clear separation of outcomes between repair of patch defects and circumferential defects. Studies involving patch defects were most likely to lead to restored oesophageal function, while circumferential replacements often led to stricture formation. The difference in outcomes was striking in one study involving both patch and circumferential defects [36]: 11 dogs with patch grafts showed no clinical signs of oesophageal dysfunction. In contrast, all 4 dogs with complete circumferential segmental graft had clinical signs of stricture. A review proposed that to achieve successful application 
the presence of intraluminal pressure is required-grafts used in vascular applications have had better outcomes than those in the oesophagus, intestine, and ureter [36]. It was postulated that since ECMs are collapsible in their native state, remodelling events occur in collapsed tubes when there is no intraluminal pressure, ultimately producing non-functional structures. This might indicate the necessity for stenting or the use of a hybrid scaffold consisting of decellularised tissue and a harder synthetic material that can provide structural support. In a study of allogeneic aorta using a Polyflex ${ }^{\circledR}$ stent in porcine, Gaujoux reported that a stent was required for at least 6 months to avoid stenosis in the graft area. Using a temporary stent to provide structure and patency to the implanted scaffold may be necessary during the initial inflammatory response and tissue remodeling process before a patent oesophageal segment is achieved [37]. The effect of a temporary stent has been evaluated in a study on oesophageal reconstruction in piglets. A $5 \mathrm{~cm}$ long circumferential gap was repaired using a recellularised scaffold of SIS, with or without the presence of an endoprothesis to temporary support the construct. The use of the scaffold alone was associated with a high mortality rate due to rapid development of oesophageal stenosis, while the interposition of the endoprothesis allowed nutritional autonomy and tissue remodeling toward an esophageal phenotype [38].

The introduction of exogenous cross-links to collagen molecules is a recognized method to stabilize collagen biomaterials and reduce antigenicity, while preserving mechanical properties and natural compliance. Different cross-linking techniques have been applied to oesophageal constructs with variable results, including the use of glutaraldehyde and genipin, showing the superiority of the latter in supporting epithelial adhesion and proliferation [39].

Since 2000, Badylak and colleagues have published work on a urinary bladder matrix (UBM)-ECM scaffold which promotes oesophageal reconstruction. In their first study, dogs underwent circumferential endomucosal resection, followed by replacement with an UBMECM scaffold leading to tissue regeneration and restored oesophageal function without 
stricture formation in any of the dogs [36]. They later showed that, while ECM dependent cellular responses were observed in vitro, there was an indistinguishable constructive outcome between the use of implanted UBM and oesophageal ECM measured 14 days post surgery [40]. The success of these studies may be due to the intact muscularis externa since musculature and both parasympathetic (vagal nerve) and intrinsic innervation systems (submucosal and myenteric plexus), which are crucial to the maintenance of peristalsis, would have been left intact. This may be the common denominator in the relatively successful in vivo studies involving patch defects where only a small segment of the oesophagus is removed. This corroborates with evidence suggesting an extensive crossover of innervation within the oesophageal wall [41]. The presence of native tissue surrounding the injury may also be crucial in providing cues for regeneration. The same cannot be said for a circumferential resection of the entire oesophagus as this would lead to the discontinuity of nerve and muscular connections. In patients with atresia however, intrinsic innervation of the oesophagus is often already abnormal. Hence, although normal peristaltic activity throughout the oesophagus is the ideal outcome to work towards, the development of a circumferential oesophageal construct that remains patent post implantation may be a more realistic clinical outcome.

\subsubsection{Decellularisation Methods}

The different methods of decellularisation must all balance the trade-offs between complete cell removal to minimise antigenicity, and preservation of structural and biological characteristics of the matrix. Decellularising methods are based on the combined effect of different agents [42], which can include:

1) Water: the first step in decellularisation often entails flushing with deionised water for a period of 24 to 72 hours [43,44,45]. Water flows into cells changing their osmotic pressure, causing them to lyse. In subsequent steps, other agents are used to remove cellular debris. 
2) Chemical agents: detergent such as Triton X-100 or Sodium Deoxycholate (SDC) are then often used to solubilise cell membranes and dissociate DNA from proteins $[46,47,48,49]$. A comparison between detergents by Ozeki provided evidence that SDC was a better decellularising agent compared to Triton X-100 [50]. The study found that oesophagi treated with Triton X-100 had a more enlarged appearance after decellularisation and were more fragile, while the use of SDC better maintained the mucosa and submucosal layers. Moreover, the DNA content of SDC-treated oesophagi was significantly less than that of those treated with Triton X-100. Hence SDC was better for both the preservation of ECM characteristics and DNA removal from the matrix.

2) Enzymatic agents: enzyme such as DNase, are often part of a decellularising protocol, to lyse the genetic material.

3) Physical agents: pressure and temperature are often combined with the above agents to optimise the decellularisation process.

The way the different agents have been combined and applied in specific organs and tissues has given rise to an array of decellularisation protocols. In 1975, Meezan [51] developed a protocol for isolating basement membranes from a variety of tissues, including bovine retinal and brain blood vessels. Conconi [52] later modified the protocol to include cycled repeats, producing a decellularised donor trachea that was transplanted into a patient. This method was then applied by Totonelli et al. in the decellularisation of rat small bowel and porcine oesophagus, introducing a perfusion-based approach [8,53]. The preservation of the oesophageal architecture was also demonstrated at x-ray phase contrast computed tomography (PC-CT) [54]. 


\subsubsection{Removal of Antigenic Materials}

Removal of nucleic acids and cell surface antigens such as the major histocompatibility complex are intuitively important in preventing rejection. Cells, however, are deeply anchored to their surrounding ECM and removal of all cell fragments is unlikely even with the most rigorous processing method. Additionally, the body has inherent cellular mechanisms, which facilitate the breakdown of DNA into nucleotides for future use $[55,56]$. Remnant DNA in decellularised-implanted matrices should be subject to the same degradation processes in vivo $[57,58,59]$ as part of the remodeling process. Even commercially available biological scaffolds for clinical use contain trace amounts of DNA $[60,61,62]$ and since the lengths of these fragments can also influence host response to the scafffold [60,63], some minimal criteria have been proposed to satisfy the intent of decellularisation [42].

Upon implantation, rejection may occur when there is recognition of cell membrane antigens by the immune system $[58,64,65,66]$. Particularly, the presence of the pig galactose- $\alpha 1,3-$ galactose (Gal) in xenografts has been implicated in the rejection of bioprosthetic heart valves, triggering a cascade that may lead to graft calcification and failure of the prosthesis [67]. This epitope is found in high density on the cell surface in most species but is absent in humans. The body produces large quantities of anti-Gal antibodies as a result of constant exposure to intestinal bacteria carrying the epitope. Although the decellularisation process removes most cells, cellular remnants containing the Gal epitope may still be present on the scaffold. Various strategies have been proposed to overcome this. The treatment of xenogenic tissue with $\alpha$-galactosidase has been proposed in non-decellularised porcine grafts for repair of cartilage and the human anterior cruciate ligament of the knee [68]. The production of Galdeficient pigs for the purpose of xenotransplantation has also been successful, showing that the threat of antigenic epitopes can be mitigated [69]. 
For every decellularisation process, trace amounts of host DNA or antigenic material will be present, and the burden of proof is on those developing the process to provide evidence that they do not contribute negatively to remodelling. Generally, ECM scaffolds have been shown to be degraded rapidly by host cells post-implantation [70,71], followed by the formation of site-specific functional host tissue. This process is influenced by several different factors including the tissue source, the decellularisation protocol applied and the site of implantation. Hence, process-specific animal implantation studies are necessary to investigate antigenicity of the scaffold and tissue remodelling processes [72]. Preliminary data obtained by implantation of decellularised xenogeneic scaffolds demonstrated that they induce antiinflammatory and immunosuppressive effects, characterized by a macrophage response toward an M2 phenotype and an activation of the host responses away from a classical proinflammatory TH1 profile [73].

\subsubsection{Cell Repopulation of Decellularised Scaffolds}

A decellularised construct with a well-preserved ECM provides physiological cues for cells to attach and remodel the matrix. Several attempts of scaffold repopulation have been described with the use of different protocols for cell seeding, including the ones proposed by Tan [74], Marzaro [47], Wei [75] and Sjöqvist [49] (to note, there is at present an expression of concern about this article from the Nature Communication editorial board). Alternatively, direct implantation of the acellular construct has been proposed, allowing cell recruitment to take place in vivo.

Appropriate cell types have been chosen targeting regeneration of either epithelial or muscle layers. Ohki [76] engineered oral epithelial cells in sheets and endoscopically placed over a mucosal resection to investigate their potential to eliminate stricture formation after endoscopic mucosal resection. The sheets adhered to underlying muscle tissue at the site of resection, providing an intact stratified epithelium and there was no evidence of stricture 
formation. Wei [75] undertook a study to evaluate the combination of autologous oral mucosal epithelial cells and SIS for oesophageal repair in a canine model. The cell-seeded scaffolds showed faster recovery as demonstrated by barium oesophagram and body weight gain, and also promoted re-epithelialisation and skeletal muscle regeneration. In order to identify the best protocol for epithelial cells isolation and culture, Maghsoudlou and colleagues [77] have compared three commonly used techniques, including 1) mincing of the mucosa followed by trypsin incubation, 2) trypsin incubation of intact mucosa, 3) mucosa culture on collagen coated wells. They demonstrate that epithelial cells can be successfully isolated from fresh mouse oesophagi using two consecutive trypsin incubations of intact mucosal sheets.

In an attempt to repopulate the muscolar layers of oesophageal scaffolds, Marzaro seeded autologous smooth muscle cells on a decellularised oesophageal segment to repair a circular defect in the thoracic oesophagus of neonate pigs [47]. Patches composing only of acellular matrices showed a more pronounced pro-inflammatory response with granulocyte and macrophage infiltration and were negative for smooth muscle actin. Whereas cell-seeded implants presented in-growth of smooth muscle cells, showing an organisation into small fascicules. Bone marrow derived mesenchymal stem cells (BMMSC) have also been thought to promote regeneration of the muscle. Tan showed that the grafting of BMMSC to SIS in a patch defect model in canine cervical oesophagus promoted re-epithelialisation with almost no pro-inflammatory reaction [74]. At 12 weeks post-surgery, long bundles of skeletal muscles and greater micro vessel density were observed. The study also showed that implanted BMMSC engrafted and differentiated into myocyte-like cells at the implant site.

In the context of scaffold repopulation, future possible options could include the use of a modular approach and seeding cells of autologous source. A modular approach would aim to recognize the biological and mechanical function of the different tissue layers in the 
oesophagus. This could involve the repopulation of individual tissue layers, combined together in a later step, or the simultaneous seeding of multiple cell types onto the same scaffold. The use of site-specific cues provided by the ECM could favour this modular approach, as seen in the regeneration of rat forearms using decellularised scaffolds repopulated with cell types of appropriate phenotype [78]. Moreover, whilst the use of autologous colonic and gastric interpositions is associated with long-term complications $[5,6,79,80]$, the use of autologous cells for recellularisation of a scaffold should not be excluded - more so if the cells can be retrieved through non-invasive methods that leave no permanent damage. Recellularising a scaffold surface with autologous cells would allow selfrecognition of the construct by the patient's immune system, avoiding a rejection response towards the cell component.

\subsubsection{Scaffolds source and Ethics}

Before development of a therapeutic, careful consideration is needed for the choice of tissue for the scaffold, its ease of obtainability, and ethical implications that may arise. The sections below outline 2 main possible tissue sources.

\subsubsection{Allogeneic scaffold source}

Since the pioneering work of Alexis Carrel, surgical transplantation of human organs from deceased and living donors to patients has become a worldwide practice, saving the lives of many $[81,82]$. Currently, the oesophagus is not an organ that is harvested for transplantation, and could be a potential tissue source. There are two difficulties to this in context of neonatal oesophageal atresia. Firstly, there is little precedent from obtaining tissues from neonates. Organ donation can only proceed if consent is available under the Human Tissue Act 2004 [81]. In neonates, there can be no consent given by the donor, hence clinicians need to consider that asking for consent and undertaking any medical procedures on the infant may be a source of distress for the family. There may also be procedural complications since it is 
difficult to confidently diagnose brain-stem death in infants from 37 weeks gestation to two months [83]. The field of neonatal organs transplantation is rapidly evolving due to the constant demand of organs as well as to the development of specific guidelines, including the ones recently produced by a task force of experts in the UK and endorsed by the local Royal College of Paediatrics [84]. So far only a few cases of neonatal organ donation have been described, a first but significant step to address issues arising from this area of transplant medicine. In this context, we cannot exclude that in the next future oesophagi of allogeneic source could be harvested from neonatal donors and decellularised to produce scaffold for LGOA repair.

The development of advanced therapeutic medical products (ATMPs) is likely to follow a mixed funding route with some private sector investment. Private investment in the development of an ATMP would require financial remuneration, but many individuals may be averse to a process where organs donated through philanthropy are used to generate a product that can be sold for profit. These issues should be explored through wider public discourse since such a model will have social and political ramifications.

\subsubsection{Xenogenic scaffold source}

One way to circumvent the issues faced by allogeneic donor material is the use of oesophageal matrices of xenogenic origin, readily available on demand and prepared in a way that reduces variability of the scaffold.

In addition to being readily available, there is also precedence for the use of porcine tissue in humans. Porcine patellar tendons have been shown to successfully replace human anterior cruciate ligaments in cases of injury [85], while glutaraldehyde fixed porcine aortic valves have been used as a bioprosthetic heart valve replacement since the $1960 \mathrm{~s}$. The latter has improved clinical outcomes by reducing the need for lifelong anticoagulation required in 
mechanical valves, but studies have also highlighted risks when xenogenic antigens were not fully removed $[65,67,86,87]$.

\section{Conclusion}

This review has described the clinical need for a tissue engineered oesophageal construct in neonatal long gap oesophageal atresia. The evolution of ideas in the field can be tracked from the use of synthetic materials for mechanical support in initial studies to the introduction of biological components such as ECM proteins and cells as part of the construct. In the field of oesophageal tissue engineering, current progress has enabled full repair of patch defects due to the retention of innervation and the presence of autologous tissue, which provides cues for regeneration. Challenges to the development of a full circumferential construct remain, including the lack of normal innervation and post implantation stricture formation.

This review has also explored the specific challenges in decellularised matrices for LGOA repair in the neonatal population. These include: 1) antenatal diagnosis, planned birth in a paediatric center that offers antenatal parental counseling, neonatal intensive care and neonatal surgery; 2) development of a full circumferential tubular construct, ideally prepared in advanced and stored as an off-the shelf product to be immediately available after birth to avoid intermediate surgery (gastrostomy) and prolonged mechanical ventilation; 3) avoidance of life-long immunosuppression that would negatively affect the growth and development of the child, preferring therefore repopulation techniques that involve cells of autologous source; 4) use of a scaffold that "grows" with the patient to avoid recurrent surgical interventions to substitute/upsize the construct itself; 4) future possible use of decellularised 
oesophagi from allogeneic sources, in view of the new guidelines on neonatal organs transplantation.

As a limitation it is important to note that, although animal studies are a necessary preclinical step, they may not closely reflect the specific clinical problem. We recognise that the research cited might not be specifically focused on the paediatric population, and knowledge had to be inferred from the valuable studies conducted on adult oesophageal reconstruction. Lastly, in vivo studies on tissue engineered oesophagus concentrated mostly on the cervical oesophagus. This may be less relevant since most clinical needs in LGOA are in the thoracic oesophagus, which has different musculature and innervation.

As the field continues to develop, the gold standard for fully functional tissue engineered constructs in LGOA has not been defined yet, leaving the medical field in need of a definitive solution for those suffering from the disease.

\section{Expert Opinion}

Long gap oesophageal atresia (LGOA) continues to represent a major challenge in paediatric surgery. Available options involve multiple stage procedures and are associated with low success rate and high risk of long-term complications.

In this context, a tissue engineering approach could be a better option. The possibility envisioned is to pre-build a tubular oesophagus substitute, transplant it in the recipient and allow it to grow with the patient for a life-long result. The initial studies involving silicon/collagen stents or absorbable constructs were associated with high rate of oesophageal leakage or stenosis. Even when successful, they only provided a regain of organ continuity while lacking in the ability to restore function. Decellularised matrices have therefore been suggested as a better tool. These can be derived from oesophagi, harvested and processed to 
remove the cell content while preserving the 3D structure of the extra cellular matrix (ECM). The latter works as a scaffold that supplies the structure and retains appropriate structural and biochemical signalling to guide cell repopulation.

While different decellularisation protocols have been described and successfully applied, more work needs to be done to overcome the following two main challenges: developing a multi-strata tubular structure and achieving appropriate repopulation of the construct itself prior to its transplant. While superficial patch repairs of the oesophageal mucosa may be achievable $[71,94,96]$, the successful rate falls when moving toward longer full-thickness tubular repairs, reaching some results only when the recipient muscularis externa is preserved [93]. Moreover the tubular matrices so far attempted have been mainly designed to repair cervical defects, while LGOA affects the intra-thoracic part of the oesophagus. This is possibly due to the ease of access during surgery and follow-up in the animal models described and to a major focus on other clinical causes of oesophageal replacement that involve the cervical portion of the organ. In our opinion, while smart polymers capable of recruiting cells in vivo could be developed in the future as off-the-shelf products, good functional outcome still requires appropriate recellularisation of the scaffold prior to transplantation. This should be ideally achieved using cells derived from the recipient to generate a non-antigenic construct, avoiding the need of a long-term immunosuppressive treatment. Cellular seeding is particularly relevant when engineering of a long segment of oesophagus is required. In order to have functional peristalsis, such oesophagus would in fact required functional integration and differentiation of neurocrest cells.

Revascularisation of the whole construct is an additional challenge. The timeframe required for spontaneous vascular growth of the recipient network into the construct is inadequate in ensuring scaffold survival in vivo. A suggested option includes wrapping the scaffold in muscle or omentum prior to the thoracic transplantation [8]. This approach would not be free 
from the complication of a second surgery and vascular reconnection. Additionally, to facilitate revascularisation in vivo, the use of appropriate angiogenesis stimuli and factors has been suggested, including studies on matrices enriched with growth factors. Type, amount and delivery profile of these factors should be carefully identified in order to optimise revascularisation. Initial release of vascular endothelial growth factor (VEGF) and basic fibroblast growth factor (bFGF) could be necessary to promote the formation of new vessels, followed by their maturation guided by factors like transforming growth factor $\mathrm{b}$ (TGF-b), platelet-derived growth factor (PDGF), and angiopoietin-1 (Ang1). An intriguing suggested option is therefore to enrich the scaffolds with biodegradable micro-carriers loaded with factors and able to release them in a timely controlled fashion.

Alternatively, engineering of a vascularised oesophagus with its vascular supply could be envisaged, similarly to the jejunal transplant with vascular anastomosis. However, this is particularly difficult due to the complex vascular supply of the oesophagus and its difficult preservation after decellularization.

Lastly but not less importantly, researchers will need to translate the results achieved in animal models into a feasible and successful application in humans. This will require a further joint effort between basic research and medicine in order to create an off-the shelf product that could be developed, stored and delivered to a surgical facility to answer a patient need.

In conclusion, it has become clear how a simple decellularised matrix may not provide an efficient treatment in LGOA, unless it is further engineered and modified as to develop a more complex "smart-matrix". This could be the result of different single layer scaffolds, combined together and enriched with proangiogenic factors, possibly associated with tailor made polymers to maintain desired structure and guarantee layers interaction, and with absorbable engineered stents to avoid early stage stenosis. 
The numerous efforts and attempts described in literature have not yet identified an optimal approach in the use of decellularised matrices in LGOA. Nevertheless, the presence of promising results obtained with the use of these matrices in other organs and the growing knowledge in the field of TE represent a constant drive towards the development of a functional repair option in LGOA.

\section{Funding:}

P De Coppi is supported by the Great Ormond Street Hospital Charity, the MRC, the Wellcome Trust and the OAK Foundation.

\section{Declaration of Interest:}

P De Coppi is a National Institute for Health Research Professor. The authors have no other relevant affiliations or financial involvement with any organization or entity with a financial interest in or financial conflict with the subject matter or materials discussed in the manuscript apart from those disclosed.

\section{References}

1. Spitz, L. Oesophageal atresia. Orphanet J Rare Dis 2007;2:24.

2. Gross, R. E. The surgery of infancy and childhood; its principles and techniques. Philadelphia: Saunders, 1953.

3. Maghsoudlou P, Eaton S, De Coppi P. Tissue engineering of the esophagus. Semin Pediatr Surg 2014;23(3):127-34.

4. Malakounides G, Lyon P, Cross K, et al. Esophageal Atresia: Improved Outcome in High-Risk Groups Revisited. Eur J Pediatr Surg 2016;26(3):227-31. 
5. Ron O, De Coppi P, Pierro A. The surgical approach to esophageal atresia repair and the management of long-gap atresia: results of a survey. Semin Pediatr Surg 2009;18(1):44-9.

*Analysis of possible surgical approaches to long gap oesophageal atresia.

6. Kovesi T, Rubin S. Long-term complications of congenital esophageal atresia and/or tracheoesophageal fistula. Chest 2004;126(3):915-25.

*Review on the severity of the complications in oesophageal atresia repair, showing the need of an alternative treatment option.

7. Spitz L. Esophageal replacement: overcoming the need. Journal of pediatric surgery 2014;49(6):849-52.

8. Totonelli G, Maghsoudlou P, Fishman JM, et al. Esophageal tissue engineering: a new approach for esophageal replacement. World J Gastroenterol 2012;18(47):69007.

9. Mashimo H, Goyal RK. Physiology of normal esophageal motility. J Clin Gastroenterol 2008;42(5):610-9

10. Goyal RK, Biancani P, Phillips A, Spiro HM. Mechanical properties of the esophageal wall. J Clin Invest 1971;50(7):1456-65.

11. Berman EF. The experimental replacement of portions of the esophagus by a plastic tube. Ann Surg 1952;135(3):337-43.

12. Fryfogle JD, Cyrowski GA, Rothwell D, et al. Replacement of the middle third of the esophagus with a silicone rubber prosthesis. An experiment and clinical study. Dis Chest 1963;43:464-75.

13. Lister J, Altman RP, Allison WA. Prosthetic Substitution of Thoracic Esophagus in Puppies: Use of Marlex Mesh with Collagen or Anterior Rectus Sheath. Ann Surg $1965 ; 162(5): 812-24$. 
14. Fukushima M, Kako N, Chiba K, et al. Seven-year follow-up study after the replacement of the esophagus with an artificial esophagus in the dog. Surgery $1983 ; 93: 70-7$.

**First study on oesophageal replacement using a tubular hybrid structure in a canine model.

15. Takimoto Y, Okumura N, Nakamura $\mathrm{T}$, et al. Long-term follow-up of the experimental replacement of the esophagus with a collagen-silicone composite tube. ASAIO J 1993;39(3):M736-9.

16. Takimoto Y, Nakamura T, Teramachi M, at al. Replacement of long segments of the esophagus with a collagen-silicone composite tube. ASAIO J 1995;41(3):M605-8.

17. Earlam R, Cunha-Melo JR. Malignant oesophageal strictures: A review of techniques for palliative intubation. British Journal of Surgery 1982;69(2):61-8.

18. Liang JH, Zhou X, Zheng ZB, Liang XL. Long-term form and function of neoesophagus after experimental replacement of thoracic esophagus with nitinol composite artificial esophagus. ASAIO J 2010;56(3):232-4.

19. Nakase $\mathrm{Y}$, Nakamura T, Kin S, et al. Intrathoracic esophageal replacement by in situ tissue-engineered esophagus. J Thorac Cardiovasc Surg 2008;136(4):850-9.

20. Beckstead BL, Pan S, Bhrany AD, et al. Esophageal epithelial cell interaction with synthetic and natural scaffolds for tissue engineering. Biomaterials 2005;26(31):621728.

21. Lynen Jansen P, Klinge U, Anurov M, et al. Surgical mesh as a scaffold for tissue regeneration in the esophagus. Eur Surg Res 2004;36(2):104-11.

22. Natsume T, Ike O, Okada $\mathrm{T}$, et al. Porous collagen sponge for esophageal replacement. J Biomed Mater Res 1993;27(7):867-75. 
23. Diemer P, Markoew S, Le DQ, Qvist N. Poly-epsilon-caprolactone mesh as a scaffold for in vivo tissue engineering in rabbit esophagus. Dis Esophagus 2015;28(3):240-5.

24. Miki H, Ando N, Ozawa S, et al. An artificial esophagus constructed of cultured human esophageal epithelial cells, fibroblasts, polyglycolic acid mesh, and collagen. ASAIO J 1999;45(5):502-8.

25. Zhu Y, Chan-Park MB, Sin Chian K. The growth improvement of porcine esophageal smooth muscle cells on collagen-grafted poly(DL-lactide-co-glycolide) membrane. J Biomed Mater Res B Appl Biomater 2005;75:193-9.

26. Zhu Y, Chian KS, Chan-Park MB, et al. Protein bonding on biodegradable poly(Llactide-co- caprolactone) membrane for esophageal tissue engineering. Biomaterials $2006 ; 27: 68-78$.

27. Saxena AK, Ainoedhofer H, Hollwarth ME. Esophagus tissue engineering: in vitro generation of esophageal epithelial cell sheets and viability on scaffold. J Pediatr Surg 2009;44(5):896-901.

28. Bitar KN, Zakhem E. Tissue engineering and regenerative medicine as applied to the gastrointestinal tract. Curr Opin Biotechnol 2013;24(5):909-15.

29. Hou L, Gong C, Zhu Y. In vitro construction and in vivo regeneration of esophageal bilamellar muscle tissue. J Biomater Appl 2016;30(9):1373-84.

30. Elliott MJ, De Coppi P, Speggiorin S, et al. Stem-cell-based, tissue engineered tracheal replacement in a child: a 2-year follow-up study. Lancet 2012;380(9846):994-1000.

31. Gattazzo F, Urciuolo A, Bonaldo P. Extracellular matrix: a dynamic microenvironment for stem cell niche. Biochim Biophys Acta 2014;1840(8):2506-19.

32. Lv H, Li L, Sun M, et al. Mechanism of regulation of stem cell differentiation by matrix stiffness. Stem Cell Res Ther 2015;6:103. 
33. Lu P, Takai K, Weaver VM, Werb Z. Extracellular matrix degradation and remodeling in development and disease. Cold Spring Harb Perspect Biol 2011;3(12).

34. Hynes RO. The extracellular matrix: not just pretty fibrils. Science 2009;326(5957):1216-9.

35. Daley WP, Peters SB, Larsen M. Extracellular matrix dynamics in development and regenerative medicine. J Cell Sci 2008;121:255-64.

36. Badylak S, Meurling S, Chen M, et al. Resorbable bioscaffold for esophageal repair in a dog model. J Pediatr Surg 2000 Jul;35(7):1097-103.

**This study compares the use of two types of matrices and highlights the fundamental difference between patch and full-circumferential repair.

37. Gaujoux S, Le Balleur Y, Bruneval P, et al. Esophageal replacement by allogenic aorta in a porcine model. Surgery 2010;148(1):39-47.

38. Poghosyan T, Sfeir R, Michaud L, et al. Circumferential esophageal replacement using a tube-shaped tissue-engineered substitute: An experimental study in minipigs. Surgery 2015;158(1):266-77.

39. Bhrany AD, Lien CJ, Beckstead BL, et al. Crosslinking of an oesophagus acellular matrix tissue scaffold. J Tissue Eng Regen Med 2008;2(6):365-72.

40. Keane TJ, DeWard A, Londono R, et al. Tissue-Specific Effects of Esophageal Extracellular Matrix. Tissue Eng Part A 2015;21(17-18):2293-300.

41. Roman C. Nervous control of esophageal peristalsis. J Physiol 1966;58(1):79-108.

42. Crapo PM, Gilbert TW, Badylak SF. An overview of tissue and whole organ decellularization processes. Biomaterials 2011;32(12):3233-43.

**Detailed comparison of decellularisation techniques for complex tissues. 
43. Lai JY, Chang PY, Lin JN. Bladder autoaugmentation using various biodegradable scaffolds seeded with autologous smooth muscle cells in a rabbit model. J Pediatr Surg 2005;40(12):1869-73.

44. Chen XK, Walters TJ. Muscle-derived decellularised extracellular matrix improves functional recovery in a rat latissimus dorsi muscle defect model. J Plast Reconstr Aesthet Surg 2013;66(12):1750-8.

45. Maghsoudlou P, Totonelli G, Loukogeorgakis SP, et al. A decellularization methodology for the production of a natural acellular intestinal matrix. J Vis Exp $2013 ;(80)$.

46. Kajitani M, Wadia Y, Hinds MT, et al. Successful repair of esophageal injury using an elastin based biomaterial patch. ASAIO J 2001;47(4):342-5.

47. Marzaro M, Vigolo S, Oselladore B, et al. In vitro and in vivo proposal of an artificial esophagus. J Biomed Mater Res A 2006;77(4):795-801.

** Study on scaffold repopulation with smooth muscle cells.

48. Urita Y, Komuro H, Chen G, et al. Regeneration of the esophagus using gastric acellular matrix: an experimental study in a rat model. Pediatr Surg Int 2007;23(1):216.

49. Sjöqvist S, Jungebluth $P$, Ling Lim M, et al. Experimental orthotopic transplantation of a tissue-engineered oesophagus in rats. Nat Commun 2014;5.

50. Ozeki M, Narita Y, Kagami H, et al. Evaluation of decellularized esophagus as a scaffold for cultured esophageal epithelial cells. J Biomed Mater Res A 2006 Dec 15;79(4):771-8.

51. Meezan E, Hjelle JT, Brendel K, Carlson EC. A simple, versatile, nondisruptive method for the isolation of morphologically and chemically pure basement membranes from several tissues. Life Sci 1975;17(11):1721-32. 
52. Conconi MT, De Coppi P, Di Liddo R, et al. Tracheal matrices, obtained by a detergent-enzymatic method, support in vitro the adhesion of chondrocytes and tracheal epithelial cells. Transpl Int 2005;18(6):727-34.

53. Totonelli G, Maghsoudlou P, Garriboli M, et al. A rat decellularized small bowel scaffold that preserves villus-crypt architecture for intestinal regeneration. Biomaterials 2012; 33(12): 3401-10.

54. Hagen CK, Maghsoudlou P, Totonelli G. High contrast microstructural visualization of natural acellular matrices by means of phase-based x-ray tomography. Sci Rep $2015 ; 5: 18156$.

55. Bennett RM, Gabor GT, Merritt MM. DNA binding to human leukocytes. Evidence for a receptor-mediated association, internalization, and degradation of DNA. J Clin Invest 1985;76(6):2182-90.

56. McCoy SL, Kurtz SE, Hausman FA, et al. Activation of RAW264.7 macrophages by bacterial DNA and lipopolysaccharide increases cell surface DNA binding and internalization. J Biol Chem 2004;279(17):17217-23.

57. Record RD, Hillegonds D, Simmons C, et al. In vivo degradation of 14C-labeled small intestinal submucosa (SIS) when used for urinary bladder repair. Biomaterials 2001;22(19):2653-9.

58. Valentin JE, Badylak JS, McCabe GP, Badylak SF. Extracellular matrix bioscaffolds for orthopaedic applications. A comparative histologic study. J Bone Joint Surg Am 2006;88(12):2673-86.

59. Gilbert TW, Stewart-Akers AM, Badylak SF. A quantitative method for evaluating the degradation of biologic scaffold materials. Biomaterials 2007;28(2):147-50. 
60. Zheng MH, Chen J, Kirilak Y et al. Porcine small intestine submucosa (SIS) is not an acellular collagenous matrix and contains porcine DNA: possible implications in human implantation. J Biomed Mater Res B Appl Biomater 2005;73(1):61-7.

61. Derwin KA, Baker AR, Spragg RK, et al. Commercial extracellular matrix scaffolds for rotator cuff tendon repair. Biomechanical, biochemical, and cellular properties. J Bone Joint Surg Am 2006;88(12):2665-72.

62. Gilbert TW, Freund JM, Badylak SF. Quantification of DNA in biologic scaffold materials. J Surg Res 2009;152(1):135-9.

63. Nagata S, Hanayama R, Kawane K. Autoimmunity and the clearance of dead cells. Cell 2010;140(5):619-30.

64. Galili U, Mandrell RE, Hamadeh RM, et al. Interaction between human natural antialpha-galactosyl immunoglobulin $\mathrm{G}$ and bacteria of the human flora. Infect Immun 1988;56(7):1730-7.

65. Cooper DK, Good AH, Koren E, et al. Identification of alpha-galactosyl and other carbohydrate epitopes that are bound by human anti-pig antibodies: relevance to discordant xenografting in man. Transpl Immunol 1993;1(3):198-205.

66. Oriol R, Ye Y, Koren E, Cooper DK. Carbohydrate antigens of pig tissues reacting with human natural antibodies as potential targets for hyperacute vascular rejection in pig-to-man organ xenotransplantation. Transplantation 1993;56(6):1433-42.

67. Wong ML, Griffiths LG. Immunogenicity in xenogeneic scaffold generation: antigen removal vs. decellularization. Acta Biomater 2014;10(5):1806-16.

68. Park S, Kim WH, Choi SY, Kim YJ Removal of alpha-Gal epitopes from porcine aortic valve and pericardium using recombinant human alpha galactosidase A. J Korean Med Sci 2009;24(6):1126-31.

URL: http://mc.manuscriptcentral.com/eobt Email: David.Grech@informage 28 of 33 
69. Phelps CJ, Koike C, Vaught TD, et al. Production of alpha 1,3-galactosyltransferasedeficient pigs. Science 2003;299(5605):411-4.

70. Gilbert TW, Stewart-Akers AM, Simmons-Byrd A, Badylak SF. Degradation and remodeling of small intestinal submucosa in canine Achilles tendon repair. J Bone Joint Surg Am 2007;89(3):621-30.

71. Badylak SF, Hoppo T, Nieponice A, et al. Esophageal preservation in five male patients after endoscopic inner-layer circumferential resection in the setting of superficial cancer: a regenerative medicine approach with a biologic scaffold. Tissue Eng Part A 2011;17(11-12):1643-50.

72. Raeder RH, Badylak SF, Sheehan C et al. Natural anti-galactose alpha1,3 galactose antibodies delay, but do not prevent the acceptance of extracellular matrix xenografts. Transpl Immunol 2002;10(1):15-24.

73. Fishman JM, Lowdell MW, Urbani L, et al. Immunomodulatory effect of a decellularized skeletal muscle scaffold in a discordant xenotransplantation model. Proc Natl Acad Sci U S A 2013;110(35):14360-5.

74. Tan B, Wei RQ, Tan MY, et al. Tissue engineered esophagus by mesenchymal stem cell seeding for esophageal repair in a canine model. Journal of Surgical Research $2013 ; 182(1): 40-8$.

75. Wei RQ, Tan B, Tan MY, et al. Grafts of porcine small intestinal submucosa with cultured autologous oral mucosal epithelial cells for esophageal repair in a canine model. Exp Biol Med 2009;234(4):453-61.

76. Ohki T, Yamato M, Murakami D, et al. Treatment of oesophageal ulcerations using endoscopic transplantation of tissue-engineered autologous oral mucosal epithelial cell sheets in a canine model. Gut 2006;55(12):1704-10. 
77. Maghsoudlou P, Ditchfield D, Klepacka DH, et al. Isolation of esophageal stem cells with potential for therapy. Pediatr Surg Int 2014;30(12):1249-56.

**Comparison of different techniques in epithelial cells isolation for oesophageal scaffolds repopulation.

78. Jank BJ, Xiong L, Moser PT, et al. Engineered composite tissue as a bioartificial limb graft. Biomaterials 2015;61:246-56.

* Example of a modular approach for the regeneration of a complex composite tissue.

79. Tannuri U, Tannuri ACA, Gonçalves MEP, Cardoso SR. Total gastric transposition is better than partial gastric tube esophagoplasty for esophageal replacement in children. Diseases of the Esophagus 2008;21(1):73-7.

80. Hunter CJ, Petrosyan M, Connelly ME, et al. Repair of long-gap esophageal atresia: gastric conduits may improve outcome-a 20-year single center experience. Pediatr Surg Int 2009;25(12):1087-91.

81. Ethical Framework for Donation after Brainstem Death Consultation. UK Donation Ethics Committee, 2014. Available at: https://www.rcpe.ac.uk/consultationresponse/ethical-framework-donation-after-brainstem-death-consultation.

82. Draft guiding principles on human organ transplantation. World Health Organization, 2015. Available at: http://www.who.int/ethics/topics/transplantation_guiding_principles/en.

83. Kelso R, Embry R, Jefferson P, Robson J. Confirming death in general practice. Br J Gen Pract 2012;62(602):462-3.

84. The diagnosis of death by neurological criteria in infants less than two months old. Royal College of Paediatrics and Child Health, 2015. Available at: http://www.rcpch.ac.uk/system/files/protected/page/DNC\%20Guide\%20FINAL.pdf. 
85. Stone KR, Abdel-Motal UM, Walgenbach AW, et al. Replacement of human anterior cruciate ligaments with pig ligaments: a model for anti-non-gal antibody response in long-term xenotransplantation. Transplantation 2007;83(2):211-9.

86. Galili U. The alpha-gal epitope and the anti-Gal antibody in xenotransplantation and in cancer immunotherapy. Immunol Cell Biol 2005;83(6):674-86.

87. Manji RA, Menkis AH, Ekser B, Cooper DK Porcine bioprosthetic heart valves: The next generation. Am Heart J 2012;164(2):177-85.

Tables References

88. Chittmittrapap S, Spitz L, Kiely EM, Brereton RJ. Anastomotic leakage following surgery for esophageal atresia. J Pediatr Surg 1992;27(1):29-32.

89. Chittmittrapap S, Spitz L, Kiely EM, Brereton RJ. Anastomotic stricture following repair of esophageal atresia. J Pediatr Surg 1990;25(5):508-11.

90. Puri P, Blake N, O'Donnell B, Guiney EJ. Delayed primary anastomosis following spontaneous growth of esophageal segments in esophageal atresia. J Pediatr Surg $1981 ; 16(2): 180-3$.

91. Holcomb GW, Rothenberg SS, Bax KM, et al. Thoracoscopic repair of esophageal atresia and tracheoesophageal fistula: a multi-institutional analysis. Ann Surg $2005 ; 242(3): 422-8$

92. Pinheiro PF, Simoes e Silva AC, Pereira RM. Current knowledge on esophageal atresia. World J Gastroenterol 2012;18(28):3662-72.

93. Badylak SF, Vorp DA, Spievack AR, et al. Esophageal reconstruction with ECM and muscle tissue in a dog model. J Surg Res 2005;128(1):87-97.

94. Isch JA, Engum SA, Ruble CA, et al. Patch esophagoplasty using AlloDerm as a tissue scaffold. J Pediatr Surg 2001;36(2): 266-8. 
95. Bozuk MI, Fearing NM, Leggett PL. Use of decellularized human skin to repair esophageal anastomotic leak in humans. JSLS 2006;10(1):83-5.

96. Lopes MF, Cabrita A, Ilharco J, et al. Esophageal replacement in rat using porcine intestinal submucosa as a patch or a tube-shaped graft. Dis Esophagus 2006;19(4):254-9.

97. Clough A, Ball J, Smith GS, Leibman S. Porcine small intestine submucosa matrix (Surgisis) for esophageal perforation. Ann Thorac Surg 2011;91(2):e15-6.

98. Doede T, Bondartschuk M, Joerck C, Schulze E, Goernig M. Unsuccessful alloplastic esophageal replacement with porcine small intestinal submucosa. Artif Organs 2009; $33: 328-33$.

\section{Article highlights box:}

- Oesophageal atresia is a congenital anomaly in which the continuity of the oesophagus is interrupted and a fistula often connects the oesophagus to the trachea.

- Whilst less severe cases can be successfully corrected through surgery, long gap atresia (LGOA) is often associated with low successful rate and high risk of long-term complications. Optimal treatment has not been established.

- Tissue engineering could represent a better treatment option for patients with LGOA. Synthetic and hybrid scaffolds have been attempted, with variable suboptimal results.

- Decellularised oesophageal scaffolds are now considered a better option because: 1) preservation of oesophageal extracellular matrix mimics the 3D structure of the native organ and stimulates cell repopulation in vivo; 2) removal of cell content reduces the risk of rejection and prevents the need of life long immunosuppression and 3) natural 
1

2

3

4

5

6

7

8

9

10

11

12

13

14

15

16

17

18

19

20

21

22

23

24

25

26

27

28

29

30

31

32

33

34

35

36

37

38

39

40

41

42

43

44

45

46

47

48

49

50

51

52

53

54

55

56

57

58

59

60

constructs can "grow" with the patient through childhood, avoiding the need of multiple surgical interventions.

- Challenges in decellularised oesophageal scaffolds production include the need to identify the best tissue source and optimal decellularisation protocol, develop and maintain a tubular patent structure, repopulate the scaffolds in its different layers, stimulate revascularisation, promote structural and functional integration with the host. 
Figure 1. X-Ray findings and schematic representation of oesophageal atresia in newborns. Notice on X-Ray the feeding tube inserted and coiling in the upper oesophageal pouch suggesting Oesophageal Atresia. A: in the most common form the Tracheo-Oesophageal Fistula connects the trachea to the distal oesophagus (Type C of Gross classification) allowing the stomach to be filled with air (gastric bubble visible on X-Ray). $B$ : when the fistula is not present or is connected to the upper oesophagus (Type A and B of Gross classification) no gastric bubble can be detected on X-Ray. These forms usually require a more challenging surgical reconstruction due to the long gap between the upper and lower ends of the oesophagus.

(Fig.1)

$168 \times 231 \mathrm{~mm}(300 \times 300 \mathrm{DPI})$ 
1

2

3

4

5

6

7

8

9

10

11

12

13

14

15

16

17

18

19

20

21

22

23

24

25

26

27

28

29

30

31

32

33

34

35

36

37

38

39

40

41

42

43

44

45

46

47

48

49

50

51

52

53

54

55

56

57

58

59

60

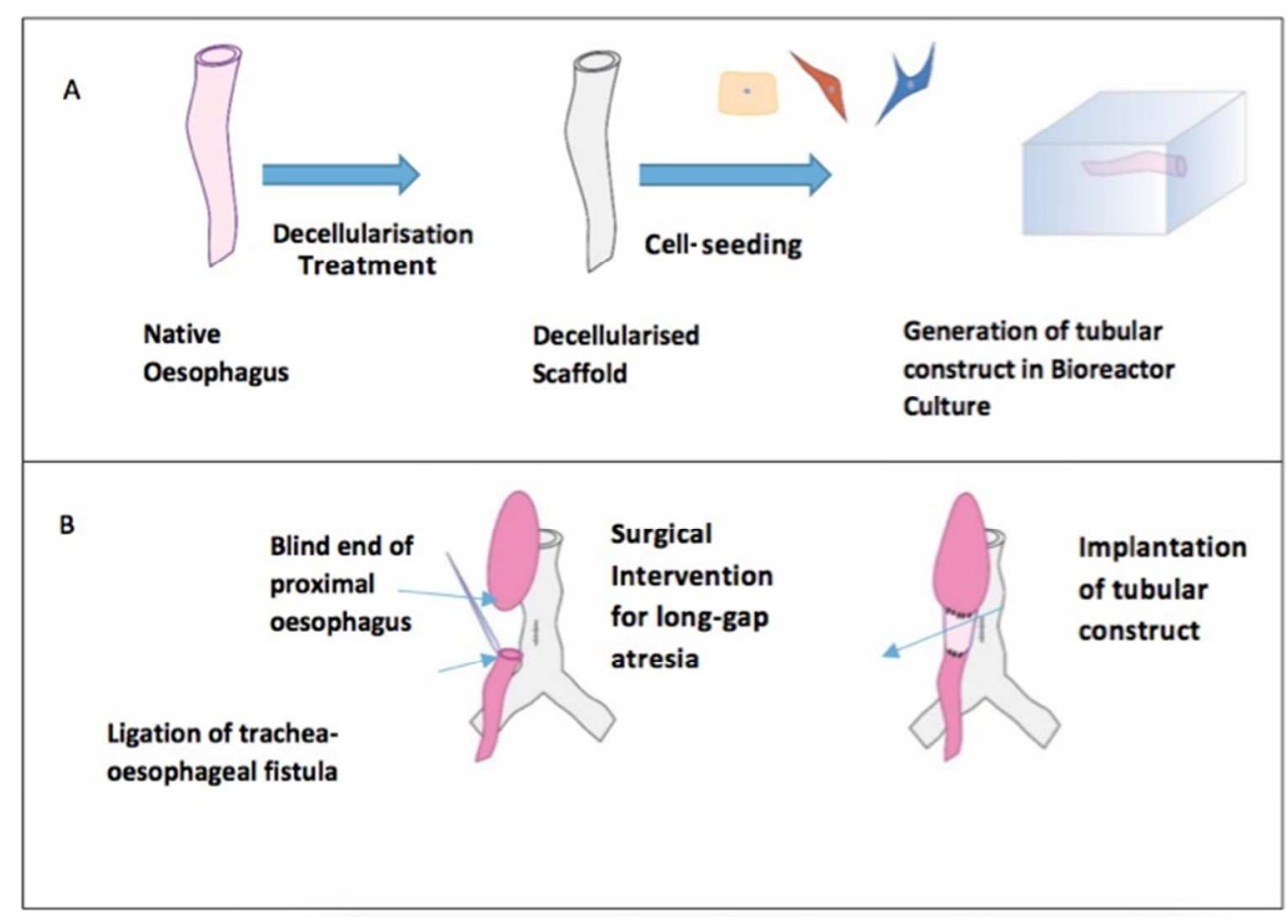

Figure 2 . Production of a tissue engineered oesophageal construct for neonatal oesophageal atresia(A). Surgical application for engineered segment in long-gap atresia with distal tracheo-oesophageal fistula (B) (Fig.2)

$196 \times 140 \mathrm{~mm}(96 \times 96$ DPI)

URL: http://mc.manuscriptcentral.com/eobt Email: David.Grech@informa.com 


\begin{tabular}{|c|c|}
\hline & \\
\hline $\begin{array}{l}15-20 \% \\
\text { Anastomotic } \\
\text { Leakage } \\
{[88]}\end{array}$ & $\begin{array}{l}\text { Less than } 30 \% \text { comprise of major leaks that occur in early } \\
\text { postoperative period ( }<48 \text { hours), presenting with life-threatening } \\
\text { tension pneumothorax. } \\
\text { Treatment: emergency surgery required for major leaks. Minor } \\
\text { leaks will heal spontaneously. }\end{array}$ \\
\hline $\begin{array}{l}30-40 \% \\
\text { Anastomotic } \\
\text { Stricture } \\
{[89]}\end{array}$ & $\begin{array}{l}\text { Risk factors include anastomotic tension, leakage, and } \\
\text { gastroesophageal reflux. } \\
\text { Treatment: most strictures will respond to one or two dilatations. }\end{array}$ \\
\hline $\begin{array}{l}40 \% \\
\text { Gastro- } \\
\text { oesophageal } \\
\text { reflux } \\
{[90,91]}\end{array}$ & $\begin{array}{l}\text { More common following anastomosis under tension. Implicated in } \\
\text { the pathogenesis of anastomotic stricture. } \\
\text { Treatment: half of the cases do not respond to antireflux } \\
\text { medication and require surgery. }\end{array}$ \\
\hline $\begin{array}{c}75-100 \% \\
\text { Dysmotility } \\
{[92]}\end{array}$ & $\begin{array}{l}\text { Uneven coordination of contractions due to abnormal innervation. } \\
\text { Dysmotility is a major factor in long-term swallowing problems. } \\
\text { Treatment: patients are advised to take fluids liberally with meals } \\
\text { and avoid foodstuffs which exacerbate the problems. }\end{array}$ \\
\hline
\end{tabular}




\begin{tabular}{|c|c|c|c|c|c|c|c|c|c|}
\hline \multirow[t]{2}{*}{ Author } & \multirow{2}{*}{$\begin{array}{l}\text { Model } \\
\text { - Animal (n) } \\
\text { - Defect site } \\
\text { - Defect type }\end{array}$} & \multirow{2}{*}{$\begin{array}{l}\text { Construct } \\
\text { - Matrix origin } \\
\text { - Decellularisati } \\
\text { on agents } \\
\text { - Type of cells } \\
\text { seeded }\end{array}$} & \multicolumn{7}{|c|}{ Outcomes } \\
\hline & & & Survival & $\begin{array}{l}\text { Vascular } \\
\text { Growth }\end{array}$ & $\begin{array}{l}\text { Mucosa / } \\
\text { epithelial } \\
\text { coverage }\end{array}$ & $\begin{array}{l}\text { Muscle } \\
\text { Organisation }\end{array}$ & Contractility & Stricture & Fibrotic Tissue \\
\hline $\begin{array}{l}\text { Badylak } \\
2000[36]\end{array}$ & $\begin{array}{l}\text { - Dog }(\mathrm{n}=15) \\
\text { - Cervical } \\
\text { - A: } 50 \% \\
\text { circular; } \\
\text { B: } 100 \% \\
\text { circular }\end{array}$ & $\begin{array}{l}\text { Porcine ECM } \\
\text { (SIS or UBM) } \\
\text { - SIS: } 0.1 \% \\
\text { Peracetic } \\
\text { Acid; UBM: } \\
1.0 \mathrm{~N} \mathrm{NaCl}\end{array}$ & & A: Yes & $\begin{array}{l}\text { A\&B: Yes } \\
\text { (after } 50 \\
\text { days) }\end{array}$ & A: Yes & A: Yes & $\begin{array}{l}\text { A: No } \\
\text { B: Yes }\end{array}$ & \\
\hline $\begin{array}{l}\text { Badylak } \\
2005[93]\end{array}$ & $\begin{array}{l}\text { - Dog }(\mathrm{n}=22) \\
\text { - Cervical } \\
\text { - Circular } \\
\text { endomucosal } \\
\text { layer } \\
\text { A: muscularis } \\
\text { externa intact } \\
\text { B: not intact }\end{array}$ & $\begin{array}{l}\text { ECM sheet } \\
\text { from UBM } \\
-0.1 \% \text { Peracetic } \\
\text { Acid }\end{array}$ & $\begin{array}{l}\text { A: } 10 / 12 \\
\text { for } 26- \\
230 \text { days } \\
\text { B: } \\
\text { Sacrificed } \\
\text { at } 3 \text { wks } \\
\text { due to } \\
\text { stricture }\end{array}$ & & & & & $\begin{array}{l}\text { A: No; } \\
\text { B: Yes but } \\
\text { lumen } \\
\text { circumferenc } \\
\text { e }<20 \% \\
\text { native }\end{array}$ & $\begin{array}{l}\text { A: Collagenous } \\
\text { connective tissue } \\
\text { present near } \\
\text { sutures } \\
\text { B: Yes }\end{array}$ \\
\hline
\end{tabular}




\begin{tabular}{|c|c|c|c|c|c|c|c|c|}
\hline $\begin{array}{l}\text { Freund } \\
2009[62]\end{array}$ & $\begin{array}{l}\text { - Dog }(\mathrm{n}=10) \\
\text { - Cervical } \\
\text { - Circular } \\
\text { endomucosal } \\
\text { resection } \\
\text { A: with scaffold } \\
\text { placement } \\
\text { B: without } \\
\text { scaffold }\end{array}$ & $\begin{array}{l}\text { ECM sheet } \\
\text { from UBM } \\
=0.1 \% \text { Peracetic } \\
\text { Acid }\end{array}$ & $\begin{array}{l}\text { A: Yes; } \\
\text { B: } 3 \\
\text { required } \\
\text { early } \\
\text { euthanasia, } \\
\text { inability to } \\
\text { tolerate oral } \\
\text { intake. }\end{array}$ & (I) Yes & $\begin{array}{l}\text { A: Yes; } \\
\text { B: Yes } \\
\text { incomplete }\end{array}$ & & A\&B: Yes & A: No \\
\hline $\begin{array}{l}\text { Isch } 2001 \\
{[94]}\end{array}$ & $\begin{array}{l}\text { - Dog }(\mathrm{n}=12) \\
\text { - Cervical } \\
\text { - } 2 \mathrm{x} 1 \mathrm{~cm} \text { patch }\end{array}$ & $\begin{array}{l}\text { DHS } \\
\text { (AlloDerm) }\end{array}$ & $\begin{array}{l}100 \% \\
\text { survival } 1-3 \\
\text { months }\end{array}$ & Yes & Yes & & No & \\
\hline $\begin{array}{l}\text { Bozuk } \\
2006[95]\end{array}$ & $\begin{array}{l}\text { - Human }(\mathrm{n}=1) \\
\text { - Thoracic } \\
\text { - Post-operative } \\
\text { dehiscence }\end{array}$ & $\begin{array}{l}\text { DHS } \\
\text { (AlloDerm) }\end{array}$ & $\begin{array}{l}\text { Patient } \\
\text { survived } \\
\text { the } \\
\text { operation }\end{array}$ & & & & No & \\
\hline $\begin{array}{l}\text { Urita } 2007 \\
{[48]}\end{array}$ & $\begin{array}{l}\text { - Rat }(\mathrm{n}=27) \\
\text { - Abdominal } \\
\text { - 3-4mm by } \\
\text { 5mm patch }\end{array}$ & $\begin{array}{l}\text { Rat GAM } \\
4 \% \text { SDC, } \\
\text { DNase I, } 1 \mathrm{M} \\
\mathrm{NaCl}\end{array}$ & $\begin{array}{l}24 \text { survived } \\
\text { without } \\
\text { complicatio } \\
\text { ns }\end{array}$ & & Yes & No & No & \\
\hline
\end{tabular}




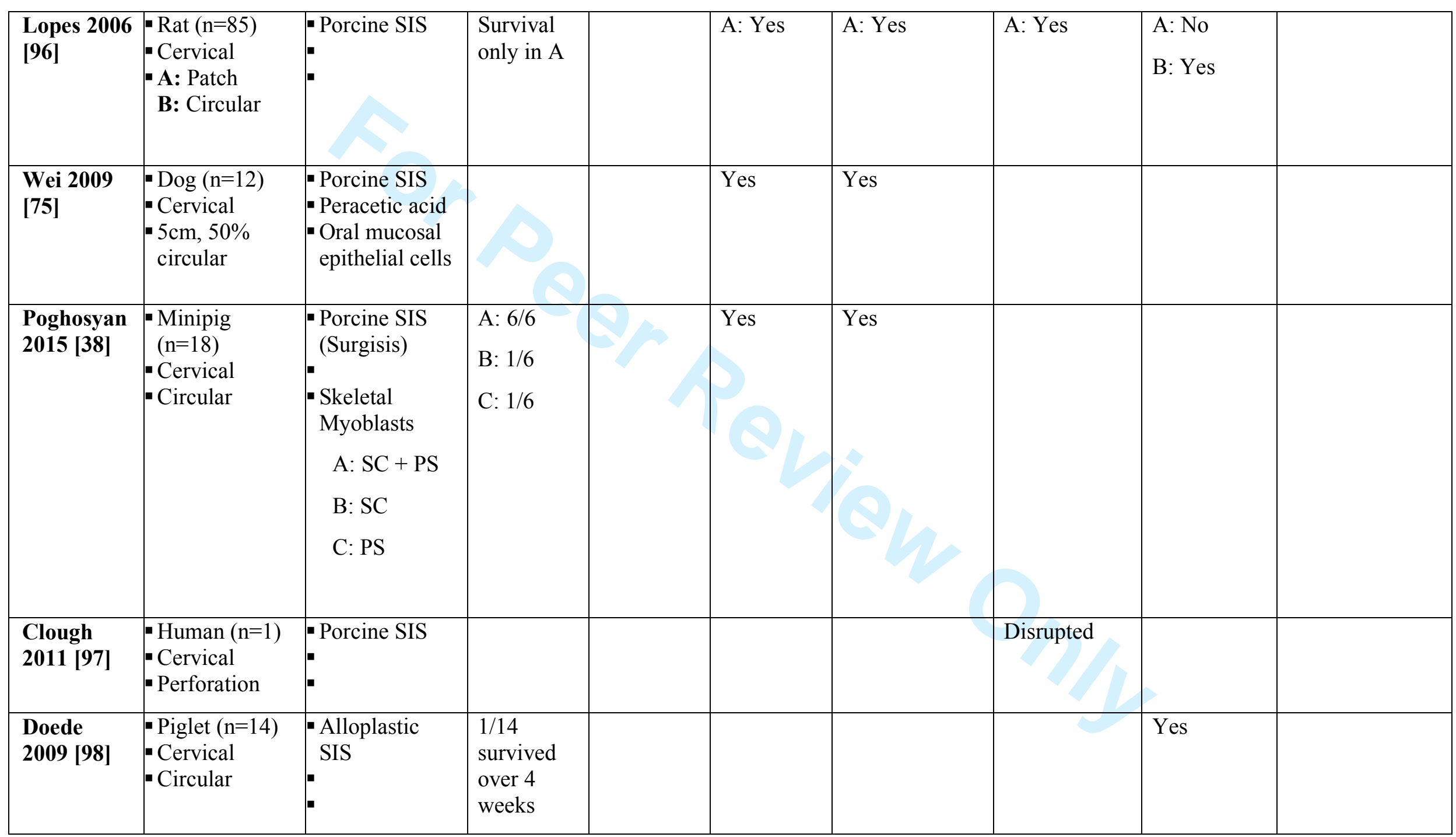




\begin{tabular}{|c|c|c|c|c|c|c|c|c|c|}
\hline $\begin{array}{l}\text { Gaujoux } \\
2010[37]\end{array}$ & $\begin{array}{l}\text { - Minipig } \\
(\mathrm{n}=18) \\
\text { - Cervical } \\
\text { - Circular }\end{array}$ & $\begin{array}{l}\text { Fresh pig } \\
\text { aortic allograft }\end{array}$ & \begin{tabular}{l|}
$33 \%$ \\
mortality \\
first month. \\
Stenting for \\
6 mths \\
crucial.
\end{tabular} & $\begin{array}{l}\text { No. } \\
\text { Stopped by } \\
\text { fibrosis }\end{array}$ & Yes & $\begin{array}{l}\text { Yes. Fascicles } \\
\text { and bundles } \\
\text { observed }\end{array}$ & No & Yes & Yes \\
\hline $\begin{array}{l}\text { Kajitani } \\
2001 \text { [46] }\end{array}$ & $\begin{array}{l}\text { - Pig }(\mathrm{n}=10) \\
\text { - Distal } \\
\text { - Circular }\end{array}$ & $\begin{array}{l}\text { Pig Aorta } \\
\text { - DNase-I; } \\
\text { Triton-X }\end{array}$ & $\begin{array}{l}10 / 10 \\
\text { survived } \\
\text { over } 6-16 \\
\text { wks }\end{array}$ & & Yes & & & Yes & \\
\hline $\begin{array}{l}\text { Marzaro } \\
2006 \text { [47] }\end{array}$ & $\begin{array}{l}\text { - Pig }(\mathrm{n}=6) \\
\text { - Thoracic } \\
\text { - Circular }\end{array}$ & $\begin{array}{l}\text { - Osophagus } \\
\text { 4\% SDC, } \\
\text { DNase-I, 1M } \\
\text { NaCl } \\
\text { - Autologus } \\
\text { Smooth } \\
\text { Muscle Cell }\end{array}$ & & 5 & $\begin{array}{l}\text { Yes } \\
\text { Capillary } \\
\text { ingrowth } \\
\text { observed }\end{array}$ & $\begin{array}{l}\text { Yes } \\
\text { Fasciclues } \\
\text { observed }\end{array}$ & & & \\
\hline $\begin{array}{l}\text { Sjoqvist } \\
2013 \text { [48] }\end{array}$ & $\begin{array}{l}\text { - Rat }(\mathrm{n}=10) \\
\text { - Cervical } \\
\text { - Circular }\end{array}$ & $\begin{array}{l}\text { - Oeesophagus } \\
\text { - 4\% SDC, } \\
\text { DNase-I, } \\
\text { EDTA } \\
\text { - Mesenchymal } \\
\text { Stromal Cell }\end{array}$ & $\begin{array}{l}\text { 10/10, } 14 \\
\text { days }\end{array}$ & Yes & Yes & Yes & & & \\
\hline
\end{tabular}




\begin{tabular}{|c|c|c|}
\hline $\begin{array}{l}\text { Aspect } \\
\text { Characterised }\end{array}$ & Technique & Examples \\
\hline \multirow[t]{5}{*}{ ECM architecture } & Staining & $\begin{array}{l}\text { Hematoxylin and Eosin, Masson's } \\
\text { Trichrome, Alcian Blue, Van- } \\
\text { Gieson's stain }\end{array}$ \\
\hline & Immunohistochemistry & $\begin{array}{l}\text { Laminin, Fibronectin, Collagen I \& } \\
\text { IV, Elastin }\end{array}$ \\
\hline & Protein & Collagen, Glycosaminoglycan \\
\hline & Mechanical Tests & $\begin{array}{l}\text { Pressure vs Distensibility, Burst } \\
\text { Pressure, Force at break, } \% \\
\text { Elongation at break }\end{array}$ \\
\hline & Imaging & $\begin{array}{l}\text { Transmission Electron Microscope, } \\
\text { Scanning Electron Microscope }\end{array}$ \\
\hline \multirow[t]{3}{*}{$\begin{array}{l}\text { Immunogenicity of } \\
\text { matrix }\end{array}$} & Immunohistochemistry & $\begin{array}{l}\text { Major histocompatibility complex I \& } \\
\text { II } \\
\text { Alpha-Gal }\end{array}$ \\
\hline & Assay & DNA Assay \\
\hline & In Vivo & Subcutaneous Implantation \\
\hline \multirow[t]{2}{*}{$\begin{array}{l}\text { Potential for } \\
\text { Vascularisation }\end{array}$} & Immunohistochemistry & $\begin{array}{l}\text { Fibroblasts Growth Factor, Vascular } \\
\text { Endothelial Growth Factor, Von } \\
\text { Willebrand Factor }\end{array}$ \\
\hline & In Vivo & $\begin{array}{l}\text { Chick Chorioallantoic Membrane } \\
\text { assay, Subcutaneous Implantation }\end{array}$ \\
\hline
\end{tabular}

